PRACE NAUKOWE UNIWERSYTETU EKONOMICZNEGO WE WROCLAWIU

\title{
Maciej Żelechowski
}

Departament Analiz i Opracowań Zbiorczych GUS

Kolegium Analiz Ekonomicznych SGH

e-mail: M.Zelechowski@stat.gov.pl

\section{TERYTORIALNE DYSPROPORCJE DOSTĘPNOŚCI USEUG PUBLICZNYCH W POLSCE JAKO WYZWANIE DLA POLITYKI SPÓJNOŚCI}

\section{TERRITORIAL DISPARITIES \\ IN PUBLIC SERVICES ACCESSIBILITY IN POLAND AS A CHALLENGE FOR COHESION POLICY}

DOI: $10.15611 /$ pn.2017.465.18

JEL Classification: H41, R58

Streszczenie: Zapewnienie dostępu do usług publicznych jest jednym z zasadniczych zobowiązań państwa wobec obywateli. Zagadnienie to jest poruszane w dokumentach dotyczących polityki spójności UE. Artykuł poświęcono regionalnemu zróżnicowaniu dostępności wybranych usług publicznych w Polsce. Porównań dokonano na poziomie województw. Analiza wskazuje m.in. na znaczące zróżnicowanie międzyregionalne w zakresie selektywnej zbiórki odpadów oraz wykorzystania Internetu w kontaktach z administracją publiczną.

Słowa kluczowe: usługi publiczne, polityka spójności.

Summary: Providing the access to public services is one of the fundamental obligations of the state towards its citizens. This issue is discussed in documents concerning the EU cohesion policy. The paper is devoted to the regional diversity of access to selected public services in Poland. The comparisons were made at the level of voivodships. The analysis shows, among others, a significant variation in terms of selective waste collection and using the Internet in contacts with public administration.

Keywords: public services, cohesion policy.

\section{Wstęp}

Analizie poddano terytorialne zróżnicowanie dostępności wybranych usług publicznych w Polsce na początku nowego okresu programowania polityk UE.

Uzasadnieniem wyboru horyzontu czasowego (2014 r.) i jednostki obserwacji (województwo) jest ogólny i diagnostyczny cel badania. Wskazana byłaby jego kon- 
tynuacja, polegająca na analizie zmian w kolejnych latach okresu 2014-2020, co pozwoliłoby na ocenę postępów w zakresie wyrównywania dysproporcji. Możliwe jest pogłębienie szczegółowości terytorialnej badania, aby zdiagnozować sytuację wewnątrz poszczególnych województw.

\section{Usługi publiczne a polityka spójności UE}

Pod pojęciem usług rozumiane są przejawy ekonomicznej aktywności człowieka mające charakter niematerialny i charakteryzujące się interaktywnością pomiędzy usługobiorcą a usługodawcą. Specyficzną ich grupą są usługi publiczne.

\subsection{Definicja usług publicznych}

W gospodarce występują dobra, których konsumpcja charakteryzuje się brakiem rywalizacji i wyłączności. Usługi publiczne w wąskim rozumieniu są związane właśnie z tą kategorią dóbr (publicznych), które ze względu na nierynkowy charakter muszą być gwarantowane przez państwo. Istnieją też obszary, w których funkcjonują reguły rynkowe, jednak wskazane jest, aby państwo tworzyło w nich warunki efektywnego i społecznie skutecznego zaspokajania potrzeb. Usługi publiczne w szerszym rozumieniu obejmują również te dziedziny.

$\mathrm{W}$ badaniu przyjęto szersze rozumienie pojęcia, zgodnie z którym usługą publiczną może być każda usługa, której świadczenie leży w interesie publicznym oraz na świadczenie której państwo może mieć wpływ przez instrumenty organizacyjne lub finansowe. Jest to ujęcie zbieżne z przyjmowanym w polityce UE.

Definiowane tak usługi publiczne mogą mieć charakter:

- administracyjny,

- społeczny,

- techniczny.

\subsection{Usługi publiczne w dokumentach strategicznych}

Ważnym aspektem polityki UE jest zapewnienie spójności gospodarczej, społecznej i terytorialnej. Według strategii „Europa 2020” UE ma dążyć do rozwoju inteligentnego, zrównoważonego i sprzyjającego włączeniu społecznemu, a spójność - osiągana przez zmniejszanie dysproporcji - ma zapewnić równomierny rozkład korzyści ze wzrostu. Elementem zmniejszenia dysproporcji jest wyrównywanie dostępności i jakości usług publicznych.

Określająca strategię interwencji funduszy europejskich w latach 2014-2020 w Polsce, Umowa Partnerstwa jako kierunki działań wskazuje m.in.:

- integrację usług różnych służb publicznych,

- poprawę dostępu do niedrogich usług publicznych, 
- wzmocnienie zastosowania technologii informacyjno-komunikacyjnych w usługach publicznych.

Krajowa Strategia Rozwoju Regionalnego 2010-2020 zakłada natomiast m.in.:

- podnoszenie dostępu do usług publicznych i ich jakości,

- zmniejszanie dysproporcji w dostępie do usług publicznych,

- rozwój usług publicznych dostępnych za pośrednictwem Internetu.

\section{Regionalne zróżnicowanie dostępności usług publicznych}

Poniżej przedstawiono w przekroju województw wybrane wskaźniki reprezentujące istotne z punktu widzenia polityki spójności UE obszary usług publicznych.

\subsection{Uslugi o charakterze administracyjnym i społecznym}

Sprawna e-administracja pozwala zaoszczędzić czas i zmniejszyć koszty. Pod względem interakcji cyfrowej obywateli z urzędami Polska lokuje się na odległym 25 miejscu w UE [Śledziewska, Zięba 2016, s. 5]. Według badania z wiosny 2015 r. odsetek korzystających z Internetu w kontaktach z administracją publiczną wyniósł w naszym kraju ok. $27 \%$, wobec ok. $46 \%$ średnio w UE. Najniższy był on w woj. świętokrzyskim, najwyższy w mazowieckim, a jego zmienność w przekroju województw była znacząca (ok. 17\%).

Tabela 1. Wybrane usługi o charakterze administracyjnym i społecznym w $2014 \mathrm{r}$.

\begin{tabular}{|l|c|c|c|}
\hline \multicolumn{1}{|c|}{ Jednostka terytorialna } & $\begin{array}{c}\text { Odsetek korzystających } \\
\text { z internetu w kontaktach } \\
\text { z administracją publiczną } \\
{[\%]^{*}}\end{array}$ & $\begin{array}{c}\text { Lekarze } \\
\text { na 10 tys. } \\
\text { ludności** }\end{array}$ & $\begin{array}{c}\text { Dzieci w wieku } \\
\text { 3-5 lat na 1 miejsce } \\
\text { w placówce } \\
\text { wychowania } \\
\text { przedszkolnego }\end{array}$ \\
\hline POLSKA & 2 & 3 & 4 \\
\hline Dolnośląskie & 26,6 & 22,8 & 1,17 \\
\hline Kujawsko-pomorskie & 27,0 & 22,3 & 1,11 \\
\hline Lubelskie & 17,8 & 22,2 & 1,35 \\
\hline Lubuskie & 25,1 & 24,2 & 1,32 \\
\hline Lódzkie & 23,4 & 20,4 & 1,15 \\
\hline Małopolskie & 24,3 & 27,5 & 1,18 \\
\hline Mazowieckie & 29,8 & 22,6 & 1,17 \\
\hline Opolskie & 33,1 & 27,1 & 1,11 \\
\hline Podkarpackie & 22,4 & 18,7 & 0,93 \\
\hline Podlaskie & 25,3 & 20,4 & 1,32 \\
\hline
\end{tabular}


Tabela 1, cd.

\begin{tabular}{|l|c|c|c|}
\hline \multicolumn{1}{|c|}{1} & 2 & 3 & 4 \\
\hline Pomorskie & 23,7 & 21,4 & 1,33 \\
\hline Śląskie & 29,4 & 23,7 & 1,00 \\
\hline Świętokrzyskie & 15,6 & 22,7 & 1,36 \\
\hline Warmińsko-mazurskie & 25,3 & 20,5 & 1,37 \\
\hline Wielkopolskie & 24,8 & 15,8 & 1,09 \\
\hline Zachodniopomorskie & 25,9 & 23,7 & 1,26 \\
\hline Współczynnik zmienności $^{* * *}$ & $16,9 \%$ & $13,2 \%$ & $11,4 \%$ \\
\hline
\end{tabular}

* Według badania ankietowego GUS „Wskaźniki społeczeństwa informacyjnego” z IV 2015 r.; korzystanie w ciągu 12 miesięcy poprzedzających badanie; osoby 16-74 lata.

** Tylko pracujący z pacjentem, bez MON i MSW.

*** Wyrażony procentowo iloraz odchylenia standardowego $(S D)$ i średniej wartości cechy $(M)$, określony wzorem: $V=S D / M \times 100 \%$.

Źródło: dane GUS.

Ochrona zdrowia to specyficzny obszar usług, charakteryzujący się rozbudowaną regulacją prawną [Kożuch, Kożuch (red.) 2011, s. 42]. Kluczową rolę odgrywa tu dostępność kadry medycznej, która jest w naszym kraju niska jak na standardy europejskie. W 2014 r. liczba lekarzy na 10 tys. ludności w Polsce (ok. 23) była najniższą z notowanych w krajach UE, dla których Eurostat podał dane ${ }^{1}$. Najmniej lekarzy przypadało na 10 tys. osób w woj. wielkopolskim, najwięcej w łódzkim, przy ok. 13\% zmienności między województwami.

W poprzednim okresie programowania zakładano objęcie w UE edukacją na poziomie przedszkolnym co najmniej 90\% dzieci w wieku powyżej 3 lat. Wśród zaleceń Komisji Europejskiej dla Polski sformułowanych w 2012 r. w ramach oceny Krajowego Programu Reform wymieniono znaczny wzrost miejsc w placówkach przedszkolnych. W Polsce w 2014 r. liczba dzieci w wieku 3-5 lat na 1 miejsce w placówce wychowania przedszkolnego wynosiła ok. 1,2. Względnie najlepszą dostępnością miejsc w przedszkolach charakteryzowało się woj. opolskie, a najsłabszą warmińsko-mazurskie. Wynoszący ok. 11\% współczynnik zmienności wskazuje na stosunkowo niewielkie zróżnicowanie między województwami.

\subsection{Usługi o charakterze technicznym}

Odsetek ludności korzystającej z sieci kanalizacyjnej w krajach UE, dla których Eurostat podał dane za 2014 r., wahał się od ok. 49\% w Rumunii do ok. 100\% w Danii. W Polsce wyniósł ok. 69\%; najwyższy był w woj. pomorskim, najniższy w lubelskim. Jego zmienność w przekroju województw była niezbyt duża (ok. 12\%).

W 2014 r. w Polsce ok. 20\% odpadów komunalnych było zbierane selektywnie i podlegało recyklingowi (wobec ok. 29\% średnio w UE). Najniższy był udział od-

${ }^{1}$ Najwyższy wskaźnik notowano w Austrii (ok. 50). 
padów zebranych selektywnie w woj. podlaskim, najwyższy w łódzkim. Współczynnik zmienności w przekroju województw na poziomie ok. 18\% wskazuje na znaczące zróżnicowanie.

Techniczny charakter mają także usługi z obszaru drogownictwa. W $2014 \mathrm{r}$. udział dróg o nawierzchni twardej w ogólnej długości dróg publicznych w krajach UE, które przekazały do Eurostatu porównywalne dane, wynosił od ok. 30\% (na Litwie) do ok. 100\% (m.in. w Danii). W Polsce było to ok. 69\%, w tym ok. 64\% dróg o nawierzchni twardej ulepszonej. Najwyższym udziałem dróg o nawierzchni twardej ulepszonej charakteryzowało się woj. śląskie, najniższym podlaskie. Wskaźnik odznaczał się sporą (ok. 16\%) zmiennością w przekroju województw.

Tabela 5. Wybrane usługi o charakterze technicznym w $2014 \mathrm{r}$.

\begin{tabular}{|l|c|c|c|}
\hline Jednostka terytorialna & $\begin{array}{c}\text { Odsetek ludności } \\
\text { korzystającej z sieci } \\
\text { kanalizacyjnej [\%] }\end{array}$ & $\begin{array}{c}\text { Odpady zebrane } \\
\text { selektywnie w relacji } \\
\text { do ogółu odpadów } \\
\text { komunalnych [\%] }\end{array}$ & $\begin{array}{c}\text { Odsetek długości dróg } \\
\text { publicznych } \\
\text { o nawierzchni twardej } \\
\text { ulepszonej [\%] }\end{array}$ \\
\hline POLSKA & 68,7 & 19,8 & 63,6 \\
\hline Dolnośląskie & 75,0 & 17,1 & 76,3 \\
\hline Kujawsko-pomorskie & 69,1 & 18,6 & 56,2 \\
\hline Lubelskie & 51,5 & 20,0 & 58,8 \\
\hline Lubuskie & 70,4 & 21,4 & 51,6 \\
\hline Łódzkie & 62,6 & 26,1 & 70,1 \\
\hline Małopolskie & 59,8 & 21,6 & 73,3 \\
\hline Mazowieckie & 66,7 & 17,7 & 63,8 \\
\hline Opolskie & 69,7 & 23,6 & 71,5 \\
\hline Podkarpackie & 68,7 & 18,6 & 43,8 \\
\hline Podlaskie & 63,2 & 13,9 & 51,1 \\
\hline Pomorskie & 82,0 & 18,9 & 78,8 \\
\hline Śląskie & 75,8 & 23,5 & 69,9 \\
\hline Świętokrzyskie & 56,1 & 25,9 & 53,5 \\
\hline Warmińsko-mazurskie & 73,4 & 14,1 & 64,0 \\
\hline Wielkopolskie & 69,7 & 18,3 & 63,6 \\
\hline Zachodniopomorskie & 80,4 & 17,7 & $16,2 \%$ \\
\hline Współczynnik zmienności & $12,1 \%$ & $18,4 \%$ & \\
\hline & & & \\
\hline
\end{tabular}

Źródło: dane GUS.

\section{Zakończenie}

Wśród badanych wskaźników największe różnice między województwami zaobserwowano dla udziału odpadów komunalnych zebranych selektywnie, gdzie współczynnik zmienności w przekroju województw wynosił w 2014 r. ok. 18\%, a najmniejszą zmienność (ok. 11\%) miała liczba dzieci w wieku 3-5 lat na 1 miejsce w placówce wychowania przedszkolnego. 
W przypadku pozostałych badanych usług można mówić o przeciętnej zmienności w przekroju województw, w tym nieco większe zróżnicowanie wystąpiło dla odsetka korzystających z Internetu w kontaktach z administracją publiczną i udziału długości dróg publicznych o nawierzchni twardej ulepszonej, a mniejsze dla odsetka ludności korzystającej z sieci kanalizacyjnej i lekarzy na 10 tys. ludności.

Niezależnie od dysproporcji terytorialnych warto mieć na uwadze dystans, jaki dzieli Polskę w przypadku analizowanych usług od przeciętnej dostępności w UE. Zwłaszcza niski na tle UE jest w naszym kraju odsetek mieszkańców korzystających z Internetu w kontaktach z administracją i mała liczba lekarzy w stosunku ludności.

\section{Literatura}

Begg D., Fisher S., Dornbusch R., 2003, Mikroekonomia, Polskie Wydawnictwo Ekonomiczne, Warszawa.

Duda J., Jeżowski A., Misiąg W., Nowak B., Szlachta J., Zaleski J., 2004, Mierzenie ilości i jakości uslug publicznych jako element programu rozwoju instytucjonalnego, Instytut Badań nad Gospodarką Rynkową, Warszawa.

Europa 2020. Strategia na rzecz inteligentnego i zrównoważonego rozwoju sprzyjającego właczeniu społecznemu, Komunikat Komisji Europejskiej, 2010, Bruksela.

Eurostat - Database, http://ec.europa.eu/eurostat/data/database (3.03.2016).

GUS - Bank Danych Lokalnych, https://bdl.stat.gov.pl (3.03.2016).

GUS - Portal Informacyjny Głównego Urzędu Statystycznego, http://stat.gov.pl/obszary-tematyczne/ nauka-i-technika-spoleczenstwo-informacyjne (3.03.2016).

GUS - System Monitorowania Rozwoju STRATEG, http://strateg.stat.gov.pl (3.03.2016).

Kachniarz M., 2012, Efektywność ustug publicznych - teoria i praktyka, Monografie i Opracowania UE we Wrocławiu nr 210, Wrocław.

Kożuch B., Kożuch A. (red.), 2011, Usługi publiczne - organizacja i zarządzanie, Monografie i Studia Instytutu Spraw Publicznych UJ, Kraków.

Krajowa Strategia Rozwoju Regionalnego 2010-2020: Regiony, Miasta, Obszary wiejskie, Ministerstwo Rozwoju Regionalnego, 2010, Warszawa.

Rekowski M., 2009, Mikroekonomia, Wrokopa, Poznań.

Śledziewska K., Zięba D., 2016, E-administracja w Polsce na tle Unii Europejskiej, Digital Economy Lab UW, Warszawa.

Umowa Partnerstwa. Projekt po zmianach wynikajacych z uzupetnienia zapisów o EFRM oraz po negocjacjach programów operacyjnych, Ministerstwo Rozwoju, 2015, Warszawa. 